Louisiana State University

LSU Digital Commons

Faculty Publications

Department of Biological Sciences

10-17-2007

\title{
Tarphonomus, a new genus of ovenbird (Aves: Passeriformes: Furnariidae) from South America
}

\author{
R. Terry Chesser \\ Smithsonian National Museum of Natural History \\ Robb T. Brumfield \\ Louisiana State University
}

Follow this and additional works at: https://digitalcommons.Isu.edu/biosci_pubs

\section{Recommended Citation}

Chesser, R., \& Brumfield, R. (2007). Tarphonomus, a new genus of ovenbird (Aves: Passeriformes:

Furnariidae) from South America. Proceedings of the Biological Society of Washington, 120 (3), 337-339. https://doi.org/10.2988/0006-324X(2007)120[337:TANG00]2.0.C0;2

This Article is brought to you for free and open access by the Department of Biological Sciences at LSU Digital Commons. It has been accepted for inclusion in Faculty Publications by an authorized administrator of LSU Digital Commons. For more information, please contact ir@lsu.edu. 


\title{
BioOne COMPLETE
}

\section{Tarphonomus, a new genus of ovenbird (Aves: Passeriformes: Furnariidae) from South America}

\author{
Authors: Terry Chesser, R., and Brumfield, Robb T.
}

Source: Proceedings of the Biological Society of Washington, 120(3) : 337-339

Published By: Biological Society of Washington

URL: https://doi.org/10.2988/0006324X(2007)120[337:TANGOO]2.0.CO;2

BioOne Complete (complete.BioOne.org) is a full-text database of 200 subscribed and open-access titles in the biological, ecological, and environmental sciences published by nonprofit societies, associations, museums, institutions, and presses.

Your use of this PDF, the BioOne Complete website, and all posted and associated content indicates your acceptance of BioOne's Terms of Use, available at www.bioone.org/terms-of-use.

Usage of BioOne Complete content is strictly limited to personal, educational, and non - commercial use. Commercial inquiries or rights and permissions requests should be directed to the individual publisher as copyright holder.

BioOne sees sustainable scholarly publishing as an inherently collaborative enterprise connecting authors, nonprofit publishers, academic institutions, research libraries, and research funders in the common goal of maximizing access to critical research. 


\title{
Tarphonomus, a new genus of ovenbird (Aves: Passeriformes: Furnariidae) from South America
}

\author{
R. Terry Chesser* and Robb T. Brumfield \\ (RTC) USGS Patuxent Wildlife Research Center, National Museum of Natural History, \\ Smithsonian Institution, P.O. Box 37012, Washington, D.C. 20013, U.S.A., \\ e-mail: terry.chesser@usgs.gov;
}

(RTB) LSU Museum of Natural Science, 119 Foster Hall, Louisiana State University, Baton Rouge, LA 70803, U.S.A., e-mail: brumfld@1su.edu

Abstract.-Tarphonomus, a new genus of ovenbird (Aves: Passeriformes: Furnariidae) from South America, is described. Species included in the new genus, formerly placed in Upucerthia, are T. certhioides and T. harterti.

Upucerthia is an endemic South American genus of the family Furnariidae, the type species of which is $U$. dumetaria (Saint-Hilaire, 1832). The genus is generally considered to be composed of nine species commonly known as earthcreepers (Sibley \& Monroe 1990, Dickinson 2003, Remsen 2003). Variation in plumage and bill morphology suggests that the genus includes three species groups ( $\mathrm{Re}-$ msen 2003): 1) U. dumetaria, U. albigula, $U$. jelskii, and $U$. validirostris; 2) $U$. andaecola and $U$. ruficaudus; and 3) $U$. certhioides and $U$. harterti. The ninth species, $U$. serrana, has been considered closely related to $U$. andaecola (Cory \& Hellmayr, 1925) and to both U. ruficau$d u s$ and $U$. andaecola (Ridgely \& Tudor, 1994), although it has also been paired with $U$. dumetaria (Vaurie, 1980).

As behavior of species of Upucerthia has become better known, vocalizations and habitat preferences of $U$. certhioides and $U$. harterti have been noted as being distinct from those of other members of the genus. The songs of $U$. certhioides and $U$. harterti, series of penetrating notes that increase in intensity while descending in frequency, differ markedly from those of other species of Upucerthia (Ridgely \&

* Corresponding author.
Tudor 1994, Remsen 2003), which tend to be drier and less penetrating and lack the characteristic patterns of those of the two aforementioned species (see Remsen 2003). In addition, $U$. certhioides and $U$. harterti typically occupy dense arid scrub and woodland habitats at low to middle elevations (up to $3000 \mathrm{~m}$ ), often with a dense undergrowth of terrestrial bromeliads, Dyckia spp. (Remsen et al. 1988, Kratter et al. 1993), in contrast to the more open montane scrub and grassland areas frequented by most species of Upucerthia. These differences have been judged sufficient by some (e.g., Ridgely \& Tudor 1994) to indicate that these species may be generically distinct from $U p u$ certhia.

Recent molecular data confirm that a separate genus is indeed warranted for $U$. certhioides and $U$. harterti (Fig. 1; Chesser et al. 2007). DNA sequences from all species of Upucerthia, gathered as part of a larger phylogenetic study of the family Furnariidae, indicate that $U$. certhioides and $U$. harterti form a clade closely related to Pseudocolaptes and only distantly related to Upucerthia sensu stricto. Thus, the traditional genus Upucerthia constitutes a non-monophyletic group. Upucerthia certhioides and $U$. harterti form a tight well-defined clade, 


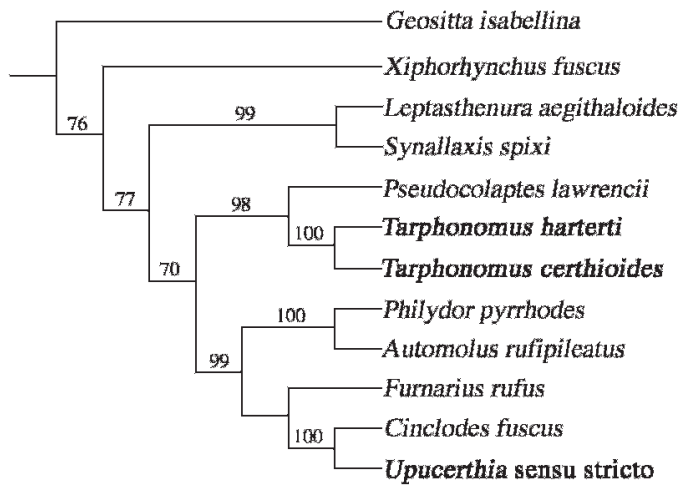

Fig. 1. Simplified molecular phylogeny of the Furnariidae, highlighting the distinctness of Tarphonomus species versus Upucerthia sensu stricto. This tree, constructed using maximum likelihood methods and modified from Chesser et al. (2007), is based on sequences of the mitochondrial genes ND3 and COII and of intron 7 of the nuclear gene $\beta$ fibrinogen. Numbers above the branches indicate bootstrap support values based on 1000 replicates.

substantially different from Pseudocolaptes, but no generic name is available for this species pair. Upucerthia certhioides was described as Anabates certhioides, but Anabates is a junior synonym of Synallaxis (Cory \& Hellmayr, 1925). Therefore, we describe a new genus for $U$. certhioides and $U$. harterti below.

Tarphonomus, genus nov.

Type species.-Anabates certhioides d'Orbigny \& Lafresnaye, 1838.

Included species.-Tarphonomus certhioides (d'Orbigny \& Lafresnaye, 1838) comb. nov., Chaco Earthcreeper; Tarphonomus harterti (Berlepsch, 1892) comb. nov., Bolivian Earthcreeper.

Diagnosis, morphology.-Medium-size passerine birds, typically $16 \mathrm{~cm}$ in total length, 18-31 g (Remsen 2003). Plumage predominantly brown; bill long, thin, very slightly decurved; upper mandible dark gray to black; lower mandible lighter, although darkish distally; upperparts dark (certhioides) or medium (harterti) brown; wings short and rounded, slightly rufescent (certhioides) or brown (harterti), remiges rufous basally; tail rounded, dark rufescent brown (certhioides) or rufous (harterti); indistinct rufous-orange (certhioides) or broad whitish (harterti) supercilium; rufous-orange (certhioides) or medium brown (harterti) forehead; throat white, contrasting with rich brown (certhioides) or buffy (harterti) underparts; sexes alike. Distinguished from Upucerthia by shorter wings (Tarphonomus wing length $62.1-71.7 \mathrm{~mm}[n=11]$; Upucerthia wing length 82.9-115.6 mm [ $=22]$ ), lower ratio of wing length to tail length (Tarphonomus wing/tail 0.92-1.03 $[n=11]$; Upucerthia wing/tail 1.13-1.36 [n = 22]), shorter bill (Tarphonomus culmen length nares to tip 16.4-19.0 $\mathrm{mm}[n=11]$; Upucerthia culmen length nares to tip $22.1-33.7 \mathrm{~mm}[n=22])$, and less strongly decurved bill. The angle of gonys is typically more pronounced in Tarphonomus than in Upucerthia.

Etymology.-The generic name, from the Greek tarphos (thicket) and nomos (place or condition for living), denotes the habitat typical of $T$. certhioides and $T$. harterti, which prefer thickets in arid scrub. The name is masculine in gender and emphasizes the distinctness of the habitat of these species from those of their former congeners in Upucerthia, which typically occupy more open arid scrub or grassland.

Molecular analyses.-Definitive placement of the new genus within the Furnariidae awaits complete phylogenetic analysis of the family, but molecular analyses indicate that Tarphonomus clearly lies outside the clade that constitutes much of the traditional subfamily Furnariinae, including Furnarius, Cinclodes, and Upucerthia (Fig. 1; Chesser et al. 2007).

\section{Acknowledgments}

We are grateful to R. C. Banks, M. S. Foster, M. L. Isler, S. L. Olson, R. P. Reynolds, and M. B. Robbins for comments and discussion concerning the manuscript. We thank R. L. Zusi for 
helpful comments regarding the morphological diagnosis, A. Kulczak for translating references from French and Latin, and L. Overstreet for bibliographic assistance. This research was supported in part by NSF grants DBI-0400797 and DEB0543562 to RTB.

\section{Literature Cited}

Berlepsch, H. 1892. [description of Upucerthia harterti].-Bericht über die XVII Jahresversammlung Allgemeinen Deutsche Ornithologischen Gesellschaft zu Berlin 1892:10.

Chesser, R. T., F. K. Barker, \& R. T. Brumfield. 2007. Four-fold polyphyly of the genus formerly known as Upucerthia, with notes on the systematics and evolution of the avian subfamily Furnariinae.-Molecular Phylogenetics and Evolution 44:1320-1332.

Cory, C. B., \& C. E. Hellmayr. 1925. Catalogue of birds of the Americas and the adjacent islands.-Field Museum of Natural History Zoological Series 13, Part 4.

Dickinson, E. C. (ed.) 2003, The Howard and Moore Complete Checklist of the Birds of the World. 3rd Edition. Princeton University Press, Princeton.
d'Orbigny, A., \& A. de Lafresnaye. 1838. [description of Anabates certhioides] in Synopsis Avium, Cl. II.-Magasin de Zoologie 8:15.

Kratter, A. W., T. S. Sillett, R. T. Chesser, J. P. O’Neill, T. A. ParkerIII, \& A. Castillo. 1993. Avifauna of a Chaco locality in Bolivia.Wilson Bulletin 105:114-141.

Remsen, J. V., Jr. 2003. Family Furnariidae (Ovenbirds). Pp. 162-357. in J. del Hoyo, A. Elliott and D. A. Christie, eds., Handbook of Birds of the World, Vol. 8: Broadbills to Tapaculos. Lynx Edicions, Barcelona.

, C. G. Schmitt, \& D. C. Schmitt. 1988. Natural history notes on some poorly known Bolivian birds, part 3.-Le Gerfaut 78:363-381.

Ridgely, R. S., \& G. Tudor. 1994. The Birds of South America, Vol. 2. University of Texas Press, Austin.

Saint-Hilaire, G. 1832. Genre Upucerthie, Upucerthia.-Nouvelles Annales du Muséum d'Histoire Naturelle Paris 1:393-395.

Sibley, C. G., \& B. L. Monroe. 1990. Distribution and Taxonomy of Birds of the World. Yale University Press, New Haven, CT.

Vaurie, C. 1980. Taxonomy and geographical distribution of the Furnariidae (Aves, Passeriformes).-Bulletin of the American Museum of Natural History 186:1-357.

Associate Editor: Gary R. Graves 